\title{
FOSSOCYTHERIDEA SWAIN \& BROWN AND PERISSOCYTHERIDEA STEPHENSON (OSTRACODA): INSIGHTS INTO PALEOSALINITY GRADIENTS OF LATE CRETACEOUS DEPOSITS FROM BRAZIL AND PORTUGAL
}

\author{
ENELISE KATIA PIOVESAN \\ Departamento de Geologia, Centro de Tecnologia, UFPE, Cidade Universitária, 50670-901, Recife, PE, Brasil. \\ katiapiovesan@gmail.com
}

\author{
MARIA CRISTINA CABRAL, ELBA ASSIS BOAVIDA, JEAN-PAUL COLIN $\dagger$ \\ Departamento de Geologia e Centro de Geologia, Faculdade de Ciências, Universidade de Lisboa, C6, 4 , 1749-016, \\ Lisboa, Portugal.mccabral@fc.ul.pt \\ GERSON FAUTH \\ Instituto Tecnológico de Micropaleontologia, UNISINOS, Av. Unisinos, 950, 93.022-000, São Leopoldo, RS, Brasil. \\ gersonf@unisinos.br
}

\begin{abstract}
Fossocytheridea Swain \& Brown and Perissocytheridea Stephenson are genera characteristic of brackish water environments. In 51 samples from the Santonian-Campanian, from the well 9-MO-13-RN, Potiguar Basin, Brazil, Fossocytheridea potiguarensis Piovesan, Cabral \& Colin, Fossocytheridea POT 1 Piovesan, Cabral \& Colin and Perissocytheridea jandairensis Piovesan, Cabral \& Colin have been identified. In the São João das Lampas section (middle Cenomanian), Lusitanian Basin, Portugal, 25 samples were studied and Fossocytheridea merlensis (Babinot \& Colin) and Perissocytheridea estribeirensis Andreu have been recognized. The distributional pattern of the FossocytherideaPerissocytheridea assemblage, combined with analysis of the abundance and diversity of marine ostracodes, suggests that in the Late Cretaceous Fossocytheridea and Perissocytheridea were euryhaline genera, and that the tolerance to salinity gradients is related to the ecology of each species and not strictly to that of the genus.
\end{abstract}

Key words: ostracodes, brackish environment, Late Cretaceous, Brazil, Portugal.

RESUMO - Fossocytheridea Swain \& Brown e Perissocytheridea Stephenson são gêneros característicos de ambientes mixohalinos. Nas 51 amostras do Santoniano-Campaniano, provenientes do testemunho 9-MO-13-RN, bacia Potiguar, Brasil, foram identificadas Fossocytheridea potiguarensis Piovesan, Cabral \& Colin, Fossocytheridea POT 1 Piovesan, Cabral \& Colin e Perissocytheridea jandairensis Piovesan, Cabral \& Colin. No afloramento de São João das Lampas (Cenomaniano médio), bacia Lusitânica, Portugal, foram estudadas 25 amostras e identificadas Fossocytheridea merlensis (Babinot \& Colin) e Perissocytheridea estribeirensis Andreu. A observação do comportamento da associação Fossocytheridea-Perissocytheridea estudada, aliada à análise da abundância e diversidade de ostracodes marinhos permite sugerir que, no Neocretáceo, tanto Fossocytheridea quanto Perissocytheridea são gêneros eurihalinos, sendo a tolerância a gradientes de salinidade relacionada à ecologia de cada espécie e não necessariamente ao gênero.

Palavras-chave: ostracodes, ambiente mixohalino, Cretáceo Superior, Brasil, Portugal.

\section{INTRODUCTION}

The cytherideids Fossocytheridea Swain \& Brown, 1964 and Perissocytheridea Stephenson, 1938 are mixohaline genera typical of marginal marine environments from the Late Cretaceous onwards. The marginal marine zones might comprise many types of environments (e.g. estuaries, deltas, open or closed lagoons, lakes, temporary or permanent ponds) subject to highly variable hydrodynamic processes (tides, currents, storms, sea level variation/time of subaerial exposure) and climatic (precipitation/evaporation rate) factors
(Frenzel \& Boomer, 2005). Important changes on physical and chemical parameters of water (e.g. salinity, temperature, $\mathrm{pH}$, dissolved oxygen), the inflow of sediment and the presence of high organic productivity are characteristic of these zones.

One of the most important population controlling factors in these zones is the salinity. Regarding it, ecologically, ostracodes may be divided into marine, brackish (mixohaline) and freshwater faunas. The ostracodes are further divided into euryhaline, i.e., the ones which tolerate a wide salinity variation, and stenohaline, which are restricted to environments with a limited salinity variation. 
Fossocytheridea is a genus widely distributed in marginal marine facies from the Aptian to the Maastrichtian of America, Europe, China, Africa and Middle East (Swain \& Brown, 1964; Babinot \& Colin, 1976; Tibert et al., 2003; Bergue et al., 2011). Previous works have already highlighted its application in the characterization of marginal marine environments (e.g. Colin et al., 1990; Tibert et al., 2002, 2003, 2009). The descendant of this genus is the cosmopolitan and euryhaline Cyprideis Jones, 1857 which is one of the most utilized Ostracoda genera in paleoecological studies in current marginal marine environments (e.g. Sandberg, 1964; Rosenfeld \& Vesper, 1977; Boomer \& Eisenhauer, 2002; Medley et al., 2007).

Perissocytheridea, in its turn, is also a mixohaline genus, typically lagoon-dwelling, which disappears almost completely from the present Gulf of Mexico bays when the salinity level reaches 30\%o (Colin et al., 1996). According to Keyser (1977), in Florida this genus is currently euryhaline, with one species preferring either mesohaline or polyhaline waters. Its origin is generally considered to have taken place on the Gondwana, and it occurs in Africa, South America, the Middle East and the south of Europe (Andreu, 1981, 1996; Babinot, 1988 a,b; Szczechura et al., 1991; Colin et al., 1996; Viviers et al., 2000; Mebrouk et al., 2011). In America this genus is recorded since the Cenomanian up to the present. Since its appearance, Perissocytheridea seems to be a mixohaline genus (e.g. Keiser, 1977; Babinot, 1988b; Nicolaidis \& Coimbra, 2008), which can be found associated both to freshwater or marine species, though in some cases the non mixohaline species are considered to be allochthonous (e.g. Coimbra et al., 2006).

The Fossocytheridea-Perissocytheridea association in the Late Cretaceous is considered as the fossil equivalent of the Cyprideis-Perissocytheridea one observed from the Neogene to present. Previous studies have shown that these two associations may occur with both marine ostracodes (Garbett \& Maddocks, 1979; Cronin, 1988; Andreu, 1996; Morsi \& Wendler, 2010) and non-marine ostracodes (Uliana \& Musacchio, 1978; Colin et al., 1996; Gross et al., 2013). The Cyprideis-Perissocytheridea genera, associated with marine ostracodes, have also been found in hyperhaline environments (Neale, 1988). Studies based on the modern living genera Cyprideis and Perissocytheridea show their potential in ecological studies. One example of this ecological approach is the work of Dias-Brito et al. (1988) at Sepetiba Bay (Rio de Janeiro State, Brazil), where they proposed distinct biofacies, within a lagoon ecosystem, based on ostracodes and foraminifers. Cyprideis and Perissocytheridea were associated in most of those biofacies, but Perissocytheridea occurred in all of them, including the ones with more marine influence.

In this work an analysis of the paleoecological response of Fossocytheridea and Perissocytheridea was carried out in Upper Cretaceous formations from Brazil and Portugal, and although occurring together the two genera seem to present different salinity tolerances.

\section{STUDY AREAS}

\section{Potiguar Basin, Brazil}

The Potiguar Basin is located in the intersection of the Equatorial Margin with the East Continental Margin, comprising an area of approximately $48,000 \mathrm{~km}^{2}$, being $21,500 \mathrm{~km}^{2}$ of emerged area and $26,500 \mathrm{~km}^{2}$ of submerged area (Figure 1). The Potiguar Basin is the easternmost of the Equatorial Margin basins, being, however, genetically related to a series of intracontinental basins of the Lower Cretaceous that represent the rift system of the Brazilian Northeast (Bertani et al., 1990).

Geologically, it is limited, to the south, east and west by the crystalline basement and it extends to the North up to the isobath of $2,000 \mathrm{~m}$. It is distributed mostly through the Rio Grande do Norte State and partially through the Ceará State (Mohriak, 2003; Pessoa Neto et al., 2007). The Potiguar Basin was formed by extensional processes during the Early Cretaceous associated with the rifting which culminated in the separation of the South-American and African plates.

Pessoa Neto et al. (2007) have divided the stratigraphical record of the Potiguar Basin into three supersequences: rift, deposited in the Early Cretaceous (Berriasian-early Aptian) and represented by fluvial-deltaic and lacustrine deposits of the Pendência and Pescada formations; post-rift, deposited during the Alagoas Stage (late Aptian-early Albian) and characterized by fluvial-deltaic deposits, with the first records of marine ingression (Alagamar Formation); and drift comprising the whole marine sedimentation occurring since the early Albian up to the Recent (including Açú, Ponta do Mel, Quebradas, Jandaíra, Ubarana, Guamaré, Macau, Tibau and Barreiras formations).

The Jandaíra Formation results from the first great marine ingression which originated from the north (Brito, 1976). This unit is mainly represented by calcarenites and bioclastic calcilutites, deposited in environments ranging from tidal flat to shallow platform (Monteiro \& Faria, 1988; Araripe \& Feijó, 1994). Rocks of this formation crop out in almost the whole emerged portion of the basin and dip at a low angle towards the Atlantic Ocean. Its thickness varies from a few dozens to $600 \mathrm{~m}$ (Pessoa Neto et al., 2007). Araripe \& Feijó (1994), re-examining some Petrobras reports, have attributed a Turonian-Campanian age to the formation, which was later corroborated by Pessoa Neto et al. (2007).

\section{Lusitanian Basin}

The Lusitanian Basin (Figure 2) is a sedimentary basin which has developed in the Western Iberian Margin during the Mesozoic, occupying an area of over $20,000 \mathrm{~km}^{2}$, from which about $2 / 3$ are emerged in the continental area (Kullberg et al., 2013). The basin is limited to the north and to the east by the Hesperian Massif (Porto-Tomar Fault), to the west by basement horsts of which one crops out at the Berlengas Islands and to the south by the Arrábida fault. Based on facies variations, thickness of the lithostratigraphic units and tectonic characteristics, the basin is divided into three sectors: northern, central and southern (Ribeiro et al., 1996; Kullberg et al., 2000). 


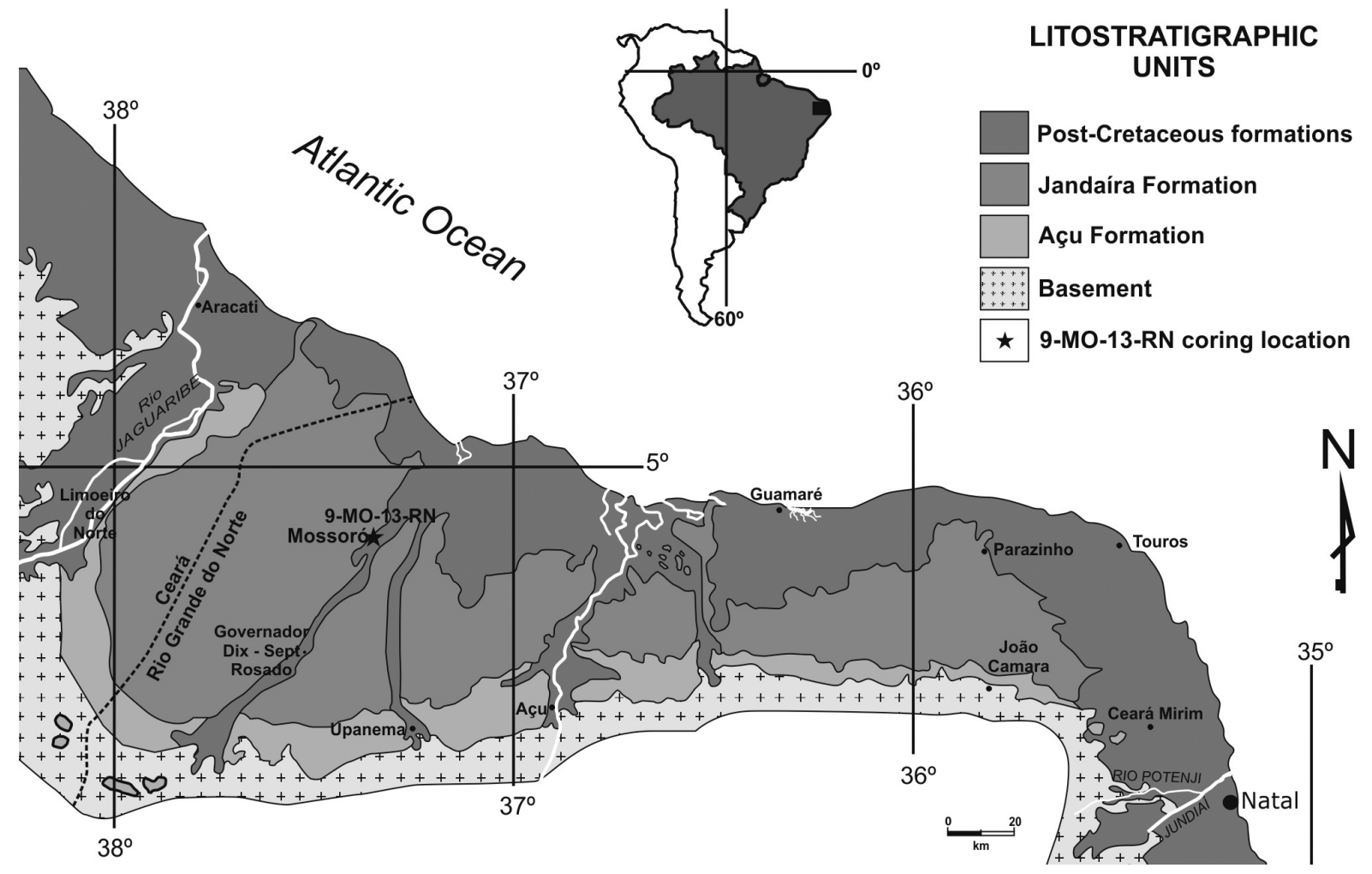

Figure 1. Map of the Potiguar Basin, onshore part, with location of the well 9-MO-13-RN (modified from Monteiro \& Faria, 1988).

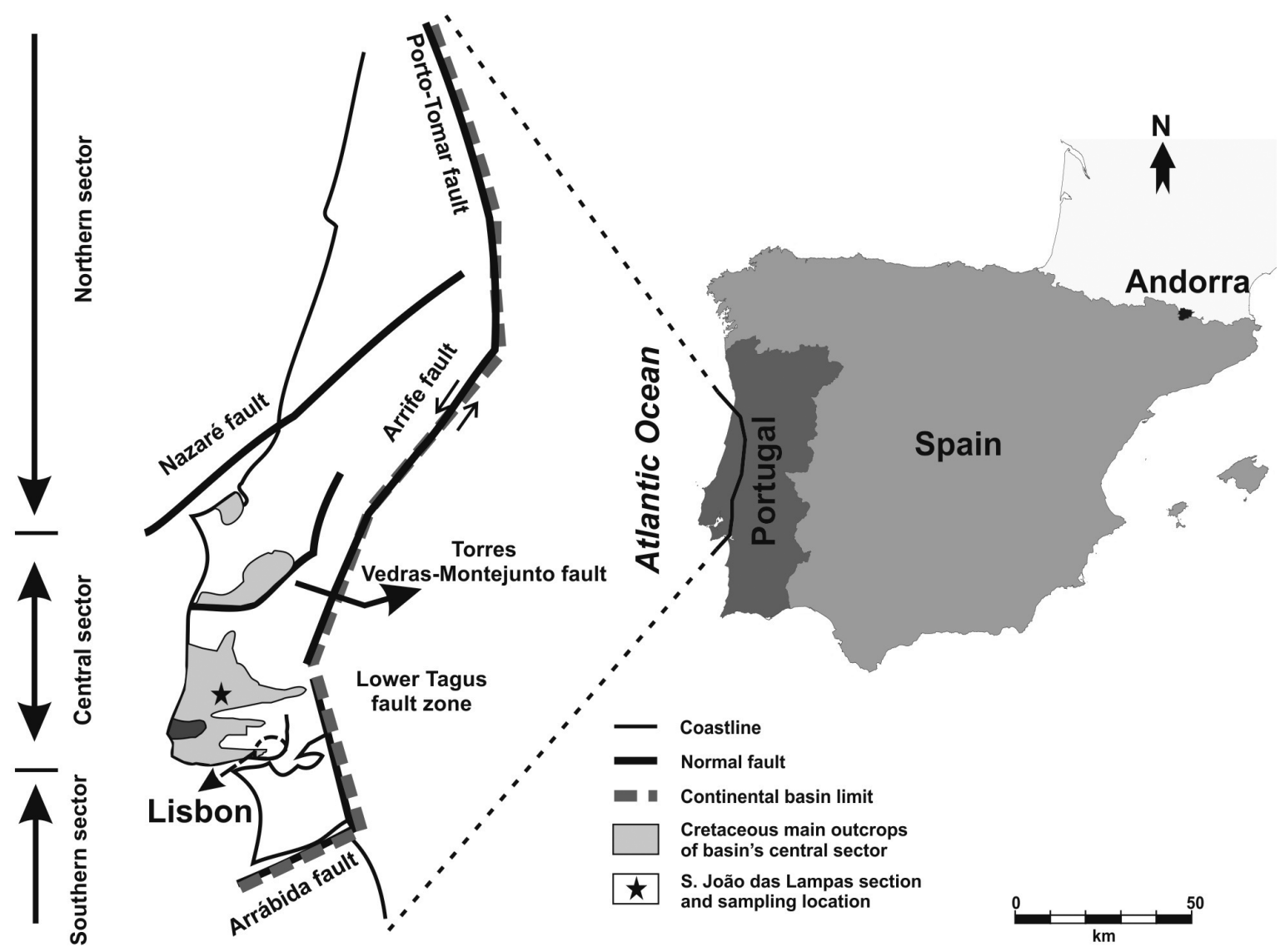

Figure 2. Onshore part of the Lusitanian Basin with its three sectors (adapted from Kullberg et al., 2013). 
The evolution of this basin was conditioned by the late Variscan faulting about 300-280 Myr ago (Ribeiro et al., 1979) and by the Mesozoic extension related to the opening of the Northern Atlantic (e.g. Kullberg et al., 2013). During this extension period many rifting episodes occurred, which have been divided by some authors in four main events, since the Triassic up to the upper Aptian (Kullberg et al., 2013).

In the Cenomanian, the Lusitanian Basin was in a postrift stage in which there was carbonate sedimentation and extension of the carbonate platform to the north and east and retraction of the clastic adjacent systems. Two formations in the Lisbon-Sintra region are part of this stage (Rey et al., 2006), being described as Belasian (old terminology) of Choffat (1885): the Caneças Formation, at the base, corresponding to the two upper levels of the Belasian, represented mainly by oyster-rich marls and marly limestones bearing many ostracodes, characteristic of marginal-lagoonal environments; and the Bica Formation, at the top (upper Cenomanian) corresponding to the "Neolobites vibrayeanus Level" (Choffat, 1885), associated with the rudist limestones from a more open subtidal marine environment.

The sedimentary sequence at São João das Lampas is stratigraphically correlated with the Lousa sequence (Cabral et al., 2008) and corresponds to the Caneças Formation (Rey et al., 2006). Being about $30 \mathrm{~m}$ thick, this sequence is represented, as many others of the same age in the Lisbon/ Sintra region (e.g. Cacém and Carenque), by massive limestone, marly limestones and marl and black clays from the lower? and middle Cenomanian (Berthou, 1984).

\section{MATERIAL AND METHODS}

The well 9-MO-13-RN was drilled in 1979 and cored a thick section of carbonates deposited in tidal flat, lagoon and bioclastic bar systems. For this study, a $20 \mathrm{~m}$ interval was analyzed, from where 51 samples were selected, covering the Santonian-Campanian interval of the Potiguar Basin. This well is located on the Mossoró town, Rio Grande do Norte State (Monteiro \& Faria, 1988; Viviers et al., 2000). The samples were weighed (approximately $60 \mathrm{~g}$ ), disaggregated with hydrogen peroxide ( $35 \%$ concentration), washed through $0.250 \mathrm{~mm}, 0.180 \mathrm{~mm}$ and $0.063 \mathrm{~mm}$ mesh sieves and dried in an oven at $60^{\circ} \mathrm{C}$. The ostracode fauna varies its diversity, abundance and preservation through the sampling of the well 9-MO-13-RN. The dominant marine species Protocosta babinoti Piovesan, Cabral \& Colin, 2014, Cophinia ovalis Piovesan, Cabral \& Colin, 2014, Semicytherura musachioi Piovesan, Cabral \& Colin, 2014, Ovocytheridea anterocompressa Piovesan, Cabral \& Colin, 2014 and Ovocytheridea triangularis Piovesan, Cabral \& Colin, 2014 are well preserved, represented by different ontogenetic stages in many samples, indicating low reworking of the material. The Perissocytheridea and Fossocytheridea species are very well preserved and with a large number of instars, highlighting that they are probably in situ. All studied specimens of the well 9-MO-13-RN are housed at Museum of Paleontology of Universidade do Vale do Rio dos Sinos, Brazil.
From the Lusitanian Basin 25 marly samples from the upper part of the São João das Lampas (middle Cenomanian) section were selected for ostracode studies. This section was studied and sampled for the first time in 1999 by M.C. Cabral and A.C. Azerêdo (University of Lisbon) and locally re-sampled in 2012 (only few samples from the upper part, $12 \mathrm{~m}, 22$ lithologically distinct levels). Each sample ( $300 \mathrm{~g})$ was dried and treated during $24 \mathrm{~h}$, at room temperature, with commercial pink oil (used for illumination) to disaggregate the marl. Then, it was washed through $2 \mathrm{~mm}, 0.5 \mathrm{~mm}, 0.150 \mathrm{~mm}$ and $0.063 \mathrm{~mm}$ mesh sieves and dried in an oven at $50^{\circ} \mathrm{C}$. The ostracodes were very abundant but not well preserved, frequently recrystallized and worn, especially the transported marine forms (generally rare). It is also possible that the lagoonal forms themselves were reworked by storm currents. A large number of instars of the mixohaline Fossocytheridea merlensis and the marine Paracaudites (Dumontina) aff. grekoffi (Babinot, 1971) were found; Perissocytheridea estribeirensis is well represented, with both adults and juveniles, in one sample only. The ostracodes of the Lusitanian Basin are housed at Cabral Collection, Departamento de Geologia, Faculdade de Ciências, Universidade de Lisboa, Portugal.

The Fossocytheridea and Perissocytheridea species of the Potiguar and Lusitanian Basins were analyzed, as well as the abundance (number of individuals) and the diversity (number of species) of ostracodes associated to them. For the calculation of these two parameters it was considered that one individual (specimen) = one carapace or one valve.

The graphic presented was elaborated using C2 software (available at http:/www.staff.ncl.ac.uk/staff/stephen.juggins/ software/C2Home.htm). The abundance was grouped according to the classes: 1-4, 5-20, 21-100, 101-200, $\geq 201$ (specimens).

\section{RESULTS AND DISCUSSION}

In the material from the well 9-MO-13-RN, Potiguar Basin (Piovesan et al., 2014b), were identified Fossocytheridea potiguarensis Piovesan, Cabral \& Colin, 2014, Fossocytheridea POT 1 Piovesan, Cabral \& Colin, 2014 (Figures 3A-F) and Perissocytheridea jandairensis Piovesan, Cabral \& Colin, 2014 (Figures 3G-I). At the São João das Lampas section the species Fossocytheridea merlensis (Babinot \& Colin, 1976) (Figures 3J-L) and Perissocytheridea estribeirensis Andreu, 1981 (Figures 3M-O) were registered.

In Potiguar Basin, Fossocytheridea is the most abundant mixohaline genus (sample $33.80 \mathrm{~m}$ ), while Perissocytheridea occurs most frequently (number of samples). The analysis of the studied species distribution (Figure 4) along the well 9-MO-13-RN, shows that Perissocytheridea jandairensis occurs associated in many levels with the marine ostracode fauna, which generally presents low diversity and abundance. In rare samples, $P$. jandairensis occurs alone $(40.90 \mathrm{~m}$; $35.60-35.00 \mathrm{~m}$ ). Furthermore, the species is most abundant in levels in which it occurs associated with Fossocytheridea potiguarensis. A similar pattern has been observed in Perissocytheridea cretacea (Piovesan et al., 2010) recorded 


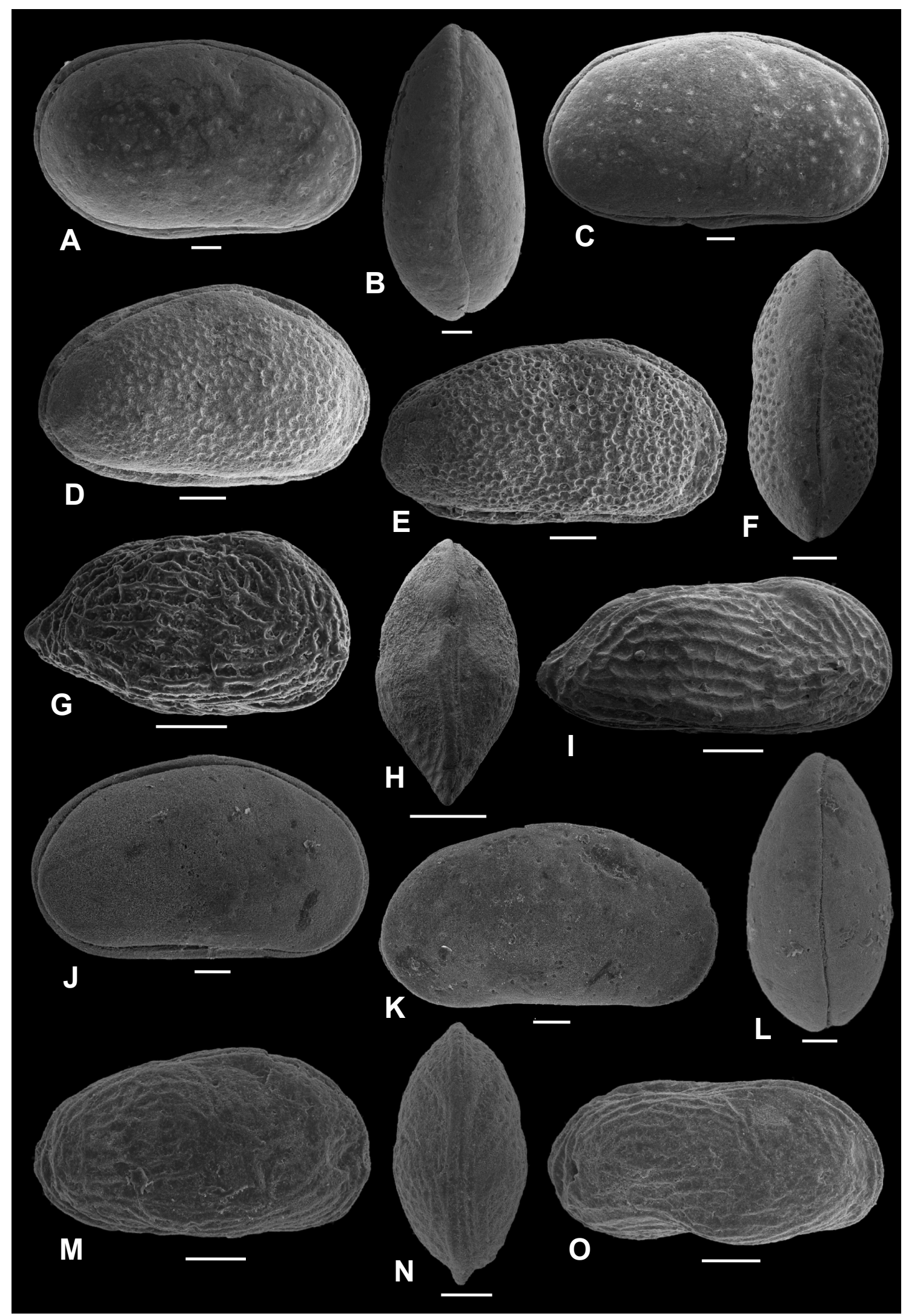

Figure 3. A-C, Fossocytheridea potiguarensis Piovesan, Cabral \& Colin, 2014. A, f, C, RV, sample 33.80 m; B, f, C, DV, sample 33.80 m; C, m, C, RV, sample 33.80 m. D-F, Fossocytheridea POT 1 Piovesan, Cabral \& Colin, 2014. D, f, C, RV, sample 38.00 m; E, m, C, RV, sample 39.60 m; F, f, C, DV, sample 33.00 m. G-I, Perissocytheridea jandairensis Piovesan, Cabral \& Colin, 2014. G, f, C, RV, sample 34.00 m; H, f, C, DV, sample $46.05 \mathrm{~m} ; \mathrm{I}, \mathrm{m}, \mathrm{C}, \mathrm{RV}$, sample $33.80 \mathrm{~m}$. J-L, Fossocytheridea merlensis (Babinot \& Colin, 1976). J, f, C, RV, sample LAP-4; K, m, RV, sample LAP-8; L, f, C, DV, sample LAP-4. M-O, Perissocytheridea estribeirensis Andreu, 1981. M, f, C, RV, sample LAP-16; N, f, C, DV, sample LAP-16; O, m, C, RV, sample LAP-16. Abbreviations: C, carapace; DV, dorsal view; RV, right view; f, female; $\mathbf{m}$, male. Scale bars $=100 \mu \mathrm{m}$. 


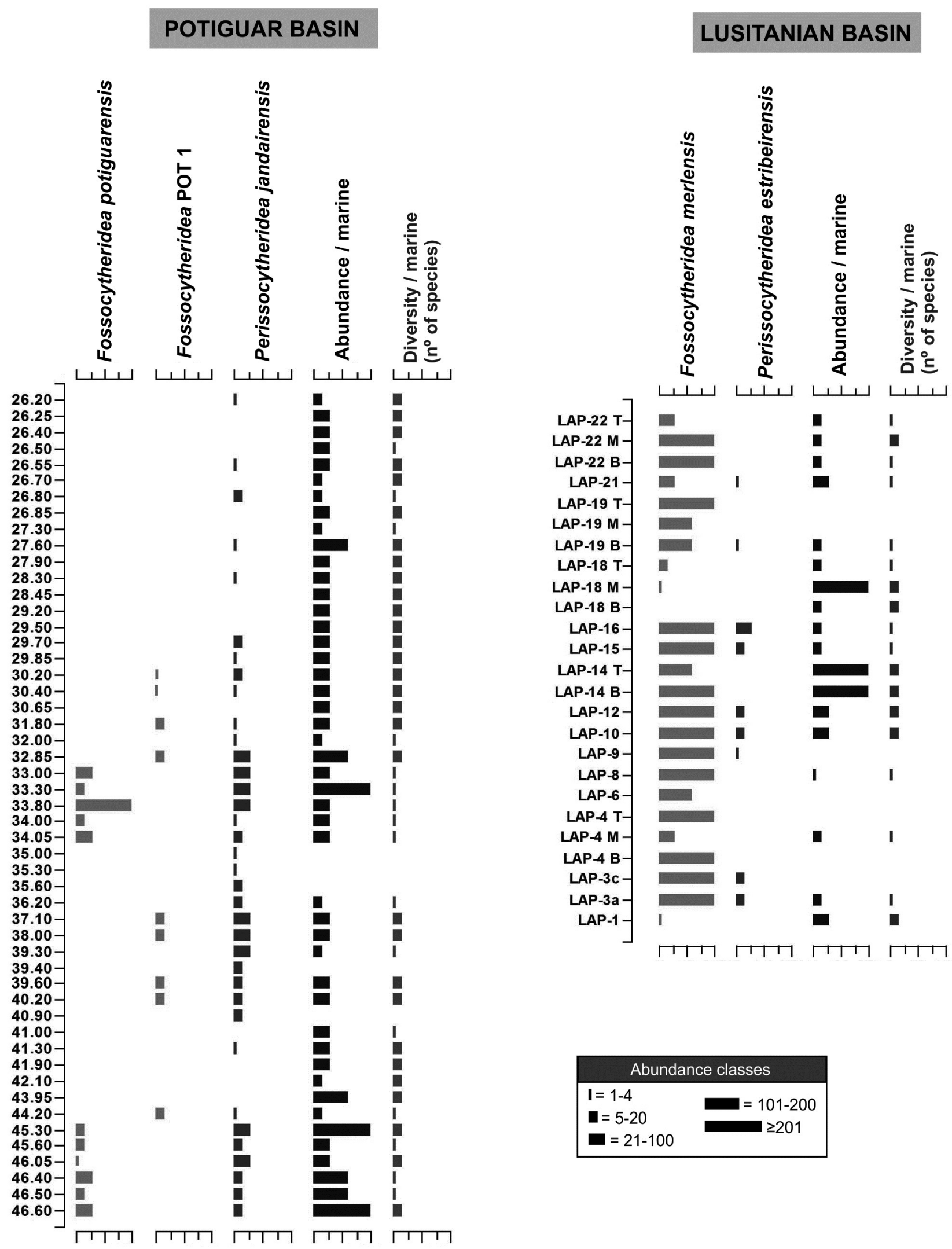

Figure 4. Species distribution of Fossocytheridea, Perissocytheridea and associated marine ostracodes in the Santonian-Campanian from the well 9-13-MO-RN, Potiguar Basin, Brazil and in the middle Cenomanian section of São João das Lampas, Lusitanian Basin, Portugal. The vertical scales in both sections represent sample levels. For the Potiguar Basin the interval sampled was 26.60 to $46.60 \mathrm{~m}$ below the surface, and in the Lusitanian Basin the samples LAP-1 to LAP-22 were collected over a section interval of $12 \mathrm{~m}$. 
in the Santonian-Campanian of the Santos Basin, Brazil. P. cretacea occurs associated with Fossocytheridea spp., when it is most abundant, but it is also found associated with typically marine species (Piovesan et al., 2010; Bergue et al., 2011). These data demonstrate the euryhaline character of the Perissocytheridea species which occurs in the Brazilian Santonian-Campanian.

The two species of the genus Fossocytheridea from the Potiguar Basin do not occur associated, which seems to indicate that they possess a different tolerance to salinity. Fossocytheridea POT 1 occurs always in association with Perissocytheridea jandairensis and in levels with the presence of the marine genera Ovocytheridea Grékoff, 1951, Cophinia Apostolescu, 1961, Protocosta Bertels, 1969, Cytherella Jones, 1849 and Soudanella Apostolescu, 1961. In the levels 34.05 to $33.80 \mathrm{~m}$, Fossocytheridea potiguarensis is very abundant and is associated with only one species from the marine genus Ovocytheridea.

In the Santonian-Campanian interval of the Santos Basin, Fossocytheridea is the mixohaline genus most diversified and abundant (Bergue et al., 2011; Fauth et al., 2012), especially in a mesohaline environment, in association with Perissocytheridea spp. On the other hand, Fossocytheridea posterodentata Bergue et al., 2011 occurs in an oligohaline environment in association with the non-marine genera Cyprois Zenker, 1854 and Ilyocypris Brady \& Norman, 1889 and charophytes.

At the São João das Lampas section (Figure 4), among the mixohaline species recorded, Fossocytheridea merlensis is significantly the most abundant and frequently species, sometimes forming monospecific associations with over a thousand individuals. F. merlensis almost always occurs in levels with low diversity and low abundance of marine specimens, such as Dolocytheridea Triebel, 1938, Cythereis Jones, 1849, Trachyleberidea Bowen, 1953, Cytherella Jones, 1849. Perissocytheridea estribeirensis, generally poorly represented, occurs always in association to F. merlensis and in levels poor in marine taxa; the greatest abundance of marine specimens occurs precisely at the levels where there is no P. estribeirensis (LAP-14B, LAP-14T and LAP-18M levels), which clearly demonstrates the mixohaline character of this species.

Further south, in the Lisbon region, in Lousa section, stratigraphically equivalent to São João das Lampas, Cabral et al. (2008) have also identified the two mixohaline ostracode species discussed: Fossocytheridea merlensis and Perissocytheridea estribeirensis. Their distribution along the Lousa section is similar to the one verified in São João das Lampas, with $F$. merlensis, much more abundant and frequently occurring (number of samples), sometimes forming monospecific associations of over a thousand individuals, but occurring also in association with marine genera (in this case F. merlensis presents a much lower quantity). At Lousa an oligohaline level attributed to a shallow water environment subject to emersion periods must be highlighted, where $F$. merlensis is associated with charophytes, Heterocypris berthoui Cabral \& Colin, 2008 and Globotalicypridea vulcanosa Cabral \& Colin, 2008, two ostracode species which range from fresh to brackish water habitats (Cabral et al., 2008). The very frequent occurrence of $F$. merlensis in this level demonstrates its capacity to tolerate very strong salinity variations, from nearly-freshwater to marine. P. estribeirensis, always low in abundance, has a similar behavior in Lousa relative to São João das Lampas, only occurring in levels without or with very few marine genera, which are much better represented in Lousa. Andreu $(1978,1981)$ described P. estribeirensis in the Cenomanian of Varge Mondar section, Lisbon region, occurring in a single level (lagoonal?), together with shallow water marine genera, such as Dolocytheridea, Schuleridea Swartz \& Swain, 1946 and Cornicythereis? Gründel, 1966.

The observation that the salinity tolerance of the genus Fossocytheridea is related to the individual species is also indicated by data from studies from other regions. Tibert $e t$ al. (2003) demonstrated that Fossocytheridea mosbyense Tibert et al., 2003 is associated with marine ostracodes and planktonic foraminifera marking the most distal brackish water deposits within an estuarine facies in the Cretaceous of Utah, USA. In more landward position, the same authors recovered a monospecific population of Fossocytheridea kirklandi Tibert et al., 2003 occurring with charophytes and non-marine gastropods. Also with respect to Fossocytheridea, Damotte (1988) in a study with samples from the Cretaceous of the Gulf of Mexico, recorded a species of the genus associated with marine genera Neocythere Mertens, 1956 and Paracypris Sars, 1866, which was interpreted as indicative of an intertidal to subtidal environment.

Perissocytheridea species have been found in different environmental contexts within the marginal marine environment. Uliana \& Musacchio (1978) recorded the species $P$. informalis Uliana \& Musacchio, 1978 associated with the non-marine ostracode genera Ilyocypris Brady \& Norman, 1889 and Wolburgiopsis Uliana \& Musacchio, 1978, in the Late Cretaceous of Argentina. The paleoecological plasticity of Perissocytheridea was also observed in Late Cretaceous species of Morocco, where Andreu (1996) recorded Perissocytheridea konatei Vivière, 1985, associated with several marine ostracode species. Likewise, Piovesan et al. (2014a) recorded two species of Perissocytheridea in the Turonian of the Potiguar Basin associated with marine ostracodes, the latter more diversified and in low abundance, in a marginal marine context.

\section{CONCLUSIONS}

Generally, the studied material from the well 9-MO-13RN, Potiguar Basin, represents a mixohaline environment with salinity variations through the sampled interval. Perissocytheridea jandairensis is an euryhaline species occurring in association with both Fossocytheridea and typically marine species. Comparing the two Fossocytheridea species from the Potiguar Basin, F. POT 1 seems restricted to less saline environments.

In São João das Lampas, Lusitanian Basin, the depositional environment is also mixohaline, with salinity variations through the studied interval. Based on the two mixohaline species present, it is concluded that 
Fossocytheridea merlensis is more tolerant to salinity variations than Perissocytheridea estribeirensis, for it occurs individually (which means that the environmental conditions must have been very stressful and may correspond both to a hypohaline environment as to a hyperhaline one), but also associated with marine species in the levels where those are most abundant. P. estribeirensis has more restricted characteristics, seeming to be limited to exclusively mixohaline environments.

Comparatively, the two studied genera show a different behavior in Brazil and in Portugal: Perissocytheridea jandairensis seems to tolerate conditions of higher salinity than Perissocytheridea estribeirensis. On the other hand, Fossocytheridea merlensis withstands important variations in salinity, which does not seem to occur in the Fossocytheridea species of the Potiguar Basin.

The results suggest that, in the Late Cretaceous, both Fossocytheridea and Perissocytheridea were euryhaline and their tolerance to salinity gradients, in the mixohaline context, is related to the ecology of each individual species.

\section{ACKNOWLEDGEMENTS}

E.K. Piovesan is indebted to CAPES for the PDSE scholarship, process number $18919 / 12-0$, for studies at the FCUL, in Portugal and CNPq (proc. 473140/2011-0) for the financial support for field activities in Potiguar Basin. G. Fauth thanks CNPq (The Brazilian Scientific and Technology Developing Council) for the grant (proc. 308544/2012-9). Thanks are also due to M.C. Viviers (Petrobras/Cenpes/ BPA) for the support in the study of the Potiguar Basin and to C.T. Bergue (itt Fossil-UNISINOS) for the discussion of the faunistic data of the Santos Basin in this work. The authors gratefully acknowledge A.C. Azerêdo (Department of Geology, FCUL) for the text revision, support in the fieldwork and in the establishment of the stratigraphical basis of the São João das Lampas section; R. Martins (Petrobras/Cenpes/ BPA), M.G. Silva (itt Fossil-UNISINOS) and T. Nunes (CBA, FCUL) for the SEM photographs. Finally, we thank A. Lord (Germany) and C.T. Bergue (Brazil) for their helpful and constructive reviews.

\section{REFERENCES}

Andreu, B. 1978. Ostracodes albiens et cénomaniens dans la zone Sud-Pyrénéenne, les Chaines Iberiques Aragonaises, le Portugal. Travaux du Laboratoire de Géologie de l'Université Paul Sabatier, Thèse $3^{\text {ème }}$ cycle, $290 \mathrm{p}$.

Andreu, B. 1981. Nouvelles espèces d'ostracodes de l'Albien et du Cénomanien d'Estremadura (Portugal). Ciências da Terra, 6:483-509.

Andreu, B. 1996. Nouvelles espèces d'ostracodes du Turonien supérieur (?)-Coniacien (?)-Santonien de la région de Boulmane, Moyen Atlas, Maroc. Systématique, biostratigraphie, paléoécologie et paléobiogéographie des associations. In: S. Jardiné; I. de Klasz \& J.P. Debenay (eds.) Géologie de l'Afrique et de l'Atlantique Sud, Actes des Colloques de géologie d'Angers, p. 483-509.
Araripe, P.T. \& Feijó, F.J. 1994. Bacia Potiguar. Boletim de Geociências da Petrobras, 8:127-141.

Babinot, J.-F. 1988a. Données préliminaires sur les associations d'ostracodes du Cénomanien de Grèce (Zone sub-pélagonienne, Argolide). Implications paléobiogéographiques et géodynamiques. Geobios, 21:435-463. doi:10.1016/S0016-6995(88)80044-5

Babinot, J.-F. 1988b. Première donnée sur les ostracodes du Cénomanien de Yougoslavie (Istrie du Sud). Geobios, 21:5-15. doi:10.1016/S0016-6995(88)80028-7

Babinot, J.-F. \& Colin, J.-P. 1976. Sarlatina n.g. (Ostracoda): sa position dans l'évolution des Cyprideidini Kollmann, 1960. In: INTERNATIONAL SYMPOSIUM ON EVOLUTION OF POST-PALEOZOIC OSTRACODA, 5, 1976. Proceedings, Hamburg NF, p. 161-174.

Bergue, C.T.; Fauth, G.; Vieira, C.E.L.; Santos, A.S. \& Viviers, M.C. 2011. New species of Fossocytheridea Swain \& Brown, 1964 (Ostracoda, Crustacea) in the Upper Cretaceous of Santos Basin, Brazil. Revista Brasileira de Paleontologia, 14:149-156. doi:10.4072/rbp.2011.2.03

Bertani, R.T.; Costa, I.G. \& Matos, R.M.D. 1990. Evolução tectonosedimentar, estilo estrutural e "habitat" do petróleo na Bacia Potiguar. In: G.P.R. Gabaglia \& E.J Milani (eds.) Origem e Evolução de Bacias Sedimentares, PETROBRAS, p. 291-310.

Berthou, P.-Y. 1984. Résumé synthetique de la stratigraphie et de la paléogéographie du Crétacé moyen et supérieur du bassin occidental portugais. Geonovas, 7:99-120.

Boomer, I. \& Eisenhauer, G. 2002. Ostracod faunas as palaeoenvironmental indicators in marginal marine environments. In: A.H. Holmes \& A.R. Chivas (eds.) The Ostracoda: applications to Quaternary research, AGU, p. 135-149. doi:10.1029/131gm07

Brito, I.M. 1976. História geológica das bacias sedimentares do Nordeste do Brasil. Anais da Academia Brasileira de Ciências, 48:463-474.

Cabral, M.C.; Azerêdo, A.C. \& Boavida; E.A. 2014. Improving palaeoecological understanding of the Cenomanian units in LisboaSintra region: the S. João das Lampas section. In: R. Rocha; J. Pais; J.C. Kullberg \& S. Finney (eds.) STRATI 2013. First International Congress on Stratigraphy: at the cutting edge of Stratigraphy, Springer, p. 1055-1060. doi:10.1007/978-3-319-04364-7_201

Cabral, M.C.; Colin, J.-P. \& Azerêdo, A.C. 2008. Taxonomy and palaeoecology of new brackish ostracod species from the Middle Cenomanian of Lousa, Lisbon region, Portugal. Palaeogeography, Palaeoclimatology, Palaeoecology, 264:250262. doi:10.1016/j.palaeo.2007.04.019

Choffat, P. 1885. Recueil de monographies stratigraphiques sur le Système Crétacique du Portugal. 1 ère étude: contrées de Cintra, de Bellas et de Lisbonne. Section des Travaux Géologiques du Portugal, Lisboa, 68 p.

Coimbra, J.C.; Costa, K.B. \& Fauth, G. 2006. Palaeoenvironmental significance of allochthonous vs. autochthonous Late Quaternary ostracodes from Imaruí Lagoon and d'Una River, southern Brazil. Revista Brasileira de Paleontologia, 9:295-302.

Colin, J.-P.; Carbonel, P. \& Olteanu, R. 1990. A review on the paleobiogeography and paleoecology of the closest groups of Cytherissa from the Mesozoic Fabanella and Vernoniella to the Cenozoic Cyprideis. Bulletin de 1'Institut de Géologie du Bassin d'Aquitaine, 47/48:119-133.

Colin, J.-P.; Tambareau, Y. \& Krasheninikov, V.A. 1996. Ostracodes limniques et lagunaires dans le Crétacé supérieur du Mali (Afrique de l'Ouest): systématique, paléoécologie et affinités paléobiogéographiques. Revue de Micropaléontologie, 39:211222. doi:10.1016/s0035-1598(96)90063-x 
Cronin, T.M. 1988. Ostracods and sea-level changes; case studies from the Quaternary of North and South Carolina, U.S. Atlantic Coast Plain. In: P. De Deckker; J.-P. Colin \& J.-P. Peypouquet (eds.) Ostracoda in the Earth Sciences, Elsevier, p. 77-88.

Damotte, R. 1988. Ostracodes crétacés du forage 95, Campagne JOIDES 10, Golfe du Mexique. Cretaceous Research, 9:159170. doi:10.1016/0195-6671(88)90015-8

Dias-Brito, D.; Moura, J.A. \& Würdig, N.L. 1988. Relationships between ecological models based on ostracods and foraminifers from Sepetiba Bay (Rio de Janeiro-Brazil). In: T. Hanai; N. Ikeya \& K. Ishizaki (eds.) Evolutionary Biology of Ostracoda, Elsevier, p. 467-484. doi:10.1016/S0920-5446(08)70202-4

Fauth, G.; Santos, A.S.; Vieira, C.E.L.; Bergue, C.T.; Musachio, E.A.; Ferreira, E.P.; Escamilla, J.H.; Carvalho, M.A.; Viviers, M.C. \& Fauth, S.B. 2012. Bioestratigrafia integrada do Cretáceo Superior da Bacia de Santos: ostracodes, carófitas e palinomorfos. Boletim de Geociencias da Petrobras, 20:229-258.

Frenzel, P. \& Boomer, I. 2005. The use of ostracods from marginal marine, brackish waters as bioindicators of modern and Quaternary environmental change. Palaeogeography, Palaeoclimatology, Palaeoecology, 225:68-92. doi:10.1016/j.palaeo.2004.02.051

Garbett, E. \& Maddocks, R.F. 1979. Zoogeography of Holocene Cytheracean ostracodes in the bays of Texas. Journal of Paleontology, 53:841-919.

Gross, M.; Ramos, M.I.; Caporaletti, M. \& Piller, W. 2013.Ostracoda (Crustacea) and their palaeoenvironmental implications for the Solimões Formation (Late Miocene, Western Amazonia, Brazil). Journal of South American Earth Science, 42:216-241. doi:10.1016/j.jsames.2012.10.002

Keyser, D. 1977. Ecology and zoogeography of Recent brackishwater Ostracoda (Crustacea) from south-west Florida. In: H. Löffler \& D. Danielopol (eds.) Aspects of Ecology and Zoogeography of Recent and Fossil Ostracoda, Dr. W. Junk b.v. Publishers, p. 207-221.

Kullberg, J.C.R. 2000. Evolução tectónica mesozóica da Bacia Lusitaniana. Universidade Nova de Lisboa, Ph.D. Thesis, 361 p.

Kullberg, J.C. et al. 2013. A Bacia Lusitaniana: estratigrafia, paleogeografia e tectónica. In: R. Dias; A. Araújo; P.Terrinha, \& J.C. Kullberg (eds.) Geologia de Portugal, Geologia Mesocenozóica de Portugal, Escolar Editora, p. 195-347.

Mebrouk, F.; Colin, J.-P. \& Hennache, F. 2011. Un gisement d'ostracodes non-marins dans l'Éocène inférieur du Djebel Amour, Atlas saharien central, Algérie : taxonomie, paléoécologie et paléobiogéographie. Carnets de Géologie / Notebooks on Geology, 4:83-97. doi:10.4267/2042/42328

Medley, P.; Tibert, N.E; Patterson, W.P.; Curran, H.A.; Greer, L. \& Colin, J.-P. 2007. Paleosalinity history of middle Holocene lagoonal and lacustrine deposits in the Enriquillo Valley, Dominican Republic based on pore morphometrics and isotope geochemistry of Ostracoda. Micropaleontology, 53:409-419. doi:10.2113/gsmicropal.53.5.409

Mohriak, W.U. 2003. Bacias sedimentares da margem continental brasileira. In: L.A. Bizzi; C. Schobbenhaus; R.M. Vidotti \& J.H. Gonçalves (eds.) Geologia, Tectônica e Recursos Minerais do Brasil, CPRM, p. 87-94.

Monteiro, M.C. \& Faria, T.R. 1988. Planície de maré no poço 9-MO-13-RN, Formação Jandaíra - um exemplo do passado. In: CONGRESSO BRASILEIRO DE GEOLOGIA, 35, 1998. Anais, Belém, p. 809-823.

Morsi, A.M.M. \& Wendler, J.E. 2010. Biostratigraphy, palaeoecology and palaeogeography of the Middle Cenomanian-Early Turonian Levant Platform in Central Jordan based on ostracods. In: C. Homberg \& M. Bachmann (eds.) Evolution of the Levant Margin and Western Arabia Platform since the Mesozoic. London, Geological Society, p. 187-210 (Special Publications 34).

Neale, J.W. 1988. Ostracodes and palaeoesalinity reconstructions. In: P. De Deckker; J.-P. Colin \& J.-P. Peypouquet (eds.) Ostracoda in the Earth Sciences, Elsevier, p. 125-155.

Nicolaidis, D.D. \& Coimbra, J.C. 2008 Perissocytheridea carrenoae sp. nov. (Crustacea, Ostracoda) and associated calcareous microfauna from Yecua Formation (Miocene), Bolivia. Revista Brasileira de Paleontologia, 11:179-186. doi:10.4072/ rbp.2008.3.04

Pessoa Neto, O.C.; Soares, U.M.; Silva, J.G.F.; Roesner, E.H.; Florencio, C.P. \& Souza, C.A.V. 2007. Bacia Potiguar. Boletim de Geociências da Petrobras, 15:357-387.

Piovesan, E.K.; Bergue, C.T. \& Fauth, G. 2010. New ostracode species from the Upper Cretaceous of the Santos Basin, Brazil. Revista Brasileira de Paleontologia, 13:175-180. doi:10.4072/ rbp.2010.3.02

Piovesan, E.K.; Cabral, M.C.; Colin, J.-P.; Fauth, G. \& Bergue, C.T. 2014a. Ostracodes from the Upper Cretaceous deposits of the Potiguar Basin, Northeastern Brazil: taxonomy, paleoecology and paleobiogeography, part 1: Turonian. Carnets de Géologie / Notebooks on Geology, 14:211-252. doi:10.4267/2042/54003

Piovesan, E.K.; Cabral, M.C.; Colin, J.-P.; Fauth, G. \& Bergue, C.T. 2014b. Ostracodes from the Upper Cretaceous deposits of the Potiguar Basin, Northeastern Brazil: taxonomy, paleoecology and paleobiogeography, part 2: Santonian-Campanian. Carnets de Géologie / Notebooks on Geology, 14:315-351. doi:10.4267/2042/54151

Rey, J.; Dinis, J.L.; Callapez, P. \& Cunha, P.P. 2006. Da rotura continental à margem passiva. Composição e evolução do Cretácico de Portugal. Cadernos de Geologia de Portugal, INETI, $75 \mathrm{p}$.

Ribeiro, A.; Antunes, M.T.; Ferreira, M.P.; Rocha, R.B.; Soares, A.F.; Zbyszewski, G.; Almeida, F.M.; Carvalho, D. \& Monteiro, J.H. 1979. Introduction à la Géologie Générale du Portugal. Lisboa, Serviços Geológicos de Portugal, 114 p.

Ribeiro, A.; Silva, J.B.; Cabral, J.; Dias, R.; Fonseca, P.; Kullberg, M.C.; Terrinha, P. \& Kullberg, J.C. 1996. Tectonics of the Lusitanian Basin. Final Report Project MILUPOBAS, Contract $\mathrm{n}^{\circ}$ JOU-CT94-0348, ICTE/GG/GeoFCUL, Lisboa, 126 p.

Rosenfeld, A. \& Vesper, B. 1977. The variability of the sieve pores in Recent and fossil species of Cyprideis torosa (Jones, 1850) as an indicator for salinity and palaeosalinity. In: H. Löffler \& D. Danielopol (eds.) Aspects of Ecology and Zoogeography of Recent and Fossil Ostracoda, Dr. W. Junk b.v. Publishers, p. 55-67.

Sandberg, P.A. 1964. The ostracod genus Cyprideis in the Americas. Stockholm University Contributions in Geology, 12:1-234.

Szczechura, J.; Abd-Elshafy, E. \& Babinot, J.-F. 1991. Late Albian to Early-Mid-Cenomanian ostracodes from Northern Galala Plateau, Egypt. Acta Paleontologica Polonica, 36:3-38.

Swain, F.M. \& Brown, P.M. 1964. Cretaceous Ostracoda from wells in the southeastern United States. Bulletin of North Carolina Department of Conservation and Development, 78:1-55.

Tibert, N.; Colin, J.-P. \& Leckie, M. 2009. Taxonomy, biostratigraphy and paleoecology of Cenomanian and Turonian ostracodes from the Western Interior Basin, Southwest Utah, USA. Revue de Micropaléontologie, 52:85-106. doi:10.1016/j. revmic.2007.02.006

Tibert, N.E.; Colin, J.P.; Leckie, R.M. \& Babinot, J.P. 2003. Revision of the ostracode genus Fossocytheridea Swain \& Brown, 1964: Mesozoic ancestral root for the modern eurytopic Cyprideis Jones. Micropaleontology, 49:205-230. doi:10.1661/00262803(2003)049[0205:rotogf]2.0.co;2 
Tibert, N.; Leckie, R.M.; Eaton, J.G.; Kirkland, J.I.; Colin, J.-P.; Eithold, E. \& Mccormick, M.E. 2002. Recognition of relative sea-level change in Upper Cretaceous coal-bearing strata: a paleocological approach using agglutinated foraminifera and ostracodes to detect key stratigraphic surfaces. In: H. Olson \& R.M. Leckie (eds.) Micropaleontologic Proxies for Sea Level Change and Stratigraphic Discontinuities. Tulsa, Society for Sedimentary Geology, p. 263-299 (Special Publication 75).

Uliana, M.A. \& Musacchio, E.A. 1978. Microfósiles calcáreos no marinos del Cretácico superior en Zampal, provincia de Mendoza, Argentina. Ameghiniana, 15:111-135.
Viviers, M.C.; Koutsoukos, E.A.M.; Silva-Telles, A.C. \& Bengtson, P. 2000. Stratigraphy and biogeographic affinities of the late Aptian-Campanian ostracods of the Potiguar and Sergipe basins in northeastern Brazil. Cretaceous Research, 21:407-455. doi:10.1006/cres.2000.0205

Received in August, 2014; accepted in December, 2014. 